\title{
PKN1 Gene
}

National Cancer Institute

\section{Source}

National Cancer Institute. PKN1 Gene. NCI Thesaurus. Code C125197.

This gene is involved in the phosphorylation of cytoskeletal intermediate filaments, cell

migration and histone modification. 